\title{
(息)
}

Citation:

Morgan, JA (2016) Brexit: Be Careful What You Wish For? Globalizations, 14 (1). pp. 118-126. ISSN 1474-774X DOI: https://doi.org/10.1080/14747731.2016.1228785

Link to Leeds Beckett Repository record:

https://eprints.leedsbeckett.ac.uk/id/eprint/3120/

Document Version:

Article (Accepted Version)

The aim of the Leeds Beckett Repository is to provide open access to our research, as required by funder policies and permitted by publishers and copyright law.

The Leeds Beckett repository holds a wide range of publications, each of which has been checked for copyright and the relevant embargo period has been applied by the Research Services team.

We operate on a standard take-down policy. If you are the author or publisher of an output and you would like it removed from the repository, please contact us and we will investigate on a case-by-case basis.

Each thesis in the repository has been cleared where necessary by the author for third party copyright. If you would like a thesis to be removed from the repository or believe there is an issue with copyright, please contact us on openaccess@leedsbeckett.ac.uk and we will investigate on a case-by-case basis. 


\section{Brexit: Be careful what you wish for?}

\section{JAMIE MORGAN}

Abstract: In this paper I focus on the British future from Brexit. The institutional form this will take is not yet fixed. However, one can consider likely outcomes based on dominant economic frameworks. From this perspective it seems unlikely that Brexit will address the actual grievances that resulted in Brexit. These transcend EU membership.

\section{Leeds Beckett University, Leeds, UK}

Keywords: Brexit, European Union, inequality, political economy

\section{Introduction}

Britain has asserted a new political geography. ${ }^{\mathrm{i}}$ Taken together the vote $23^{\text {rd }}$ June 2016 represents a sum of differently positioned disaffections, shared by an electorate drawn from the traditional left and right. These disaffections concern the quality and pressure on public services. They also concern wages and income levels, population growth and cultural change. There is a deep sense in the UK that a political elite cannot be trusted, and do not represent the electorate. Many voters also feel strongly that corporations are increasingly remote and lacking in accountability for their actions. There is a cumulative, though not cohesive, sense that, whatever its economic position in the world, Britain is also a divided system. This sense has created the grounds for misinformation, manipulation, easy targets for blame, and quick fix solutions. The British future from Brexit is not yet determined because its institutional form remains undecided. However, if dominant conceptual frameworks continue to apply then it seems unlikely that Brexit will address the underlying causes of grievances, since these transcend European Union (EU) membership. They are a product of a common political economy, understood as an ideational framework within globalizing processes. In the rest of this paper, I focus on some of the common ideational issues arising from economics and the possible consequences; other papers in this issue provide additional context.

\section{The political economy of a divisive system:}

\section{Leave and Remain as one-choice-as-no-choice?}

Whilst it may be true to say that proper consideration of EU membership was hampered by a failure to make the case effectively regarding benefits, one cannot neglect that the grievances expressed through the Referendum arose in the context of that EU membership (for context see Duroy, 2014; Longo \& Murray, 2011; Sloam, 2016). However, there is more to this issue.i The worker within the modern corporation is weaker and poorer than she was 20 years ago. Much of the contemporary analysis of capitalism conceptualises it as a globalising system of processes (Brenner et al. 2010, Peck, 2013). Differences occur within commonalities expressed as core characteristics, which create scope for, but limit the degree of, variation.iii The core is expressed through governance 
operative within the state, the region and more broadly. Governance is more than government, it involves regulatory systems and practices, which shape a socio-political economy. From this perspective, membership of the EU is a specification of more general processes. As such, the grievances that underlie Brexit may not be reducible to membership of the EU and whether one is inside or outside may not actually be the major issue. Rather, the major issue may be oppositional in a different way: grievances concerning a divisive past and present versus the potential for a more inclusive-as-fair and hence collectively legitimate future. Put another way, Brexit might be thought of as a kind of displacement activity: a way to express grievances, but where ultimately being inside or outside of the EU is not the fundamental problem, that problem is the exclusionary nature of dominant commonalities that transcend membership of the EU (Wrenn, 2014).

One can analyse dominant commonalities from various perspectives. For example, one can focus down on mainstream economics as a form of knowledge (see Lawson, 2015). One can argue that it is integral to the current forms of global, European and local governance. To focus in this way does not imply that only economics is of significance. But the nature of economics does have consequences for the social reality from which grievances can emerge (and in which xenophobia can be encouraged). A significant commonality is that in contemporary economics labour is treated as just one more factor of production, a unit cost, measured and rewarded in terms of its marginal productivity, and where the labour market is ultimately no different than any other. One makes the market efficient through augmenting the factor (labour) and by reducing 'distortions' in its 'free' interactions. Anything that intercedes between the 'market' and the interacting individual becomes an impediment to 'efficiency'. As such, the collective is immediately positioned as antithetical to this efficiency and trade unions become a systemic problem (rather than integral solution), which must be suppressed through legislation.

A tension then arises since efficiency essentially means being more (maximally) productive, enabling falling costs through time, but also triggering rewards to labour in terms of higher wages to reflect an individual's contribution. Yet for this to actually function then the individual must be the genuine and identifiable source of production, whereas one might argue production involves an organized set of relations and co-operations. The individual in the labour market must also be able to do what collective representation previously did, and now is hampered in doing. That is, be aware of and adequately represent their own interests in the context of inscribed employment rights, and in the context of assumed competition of each and every worker against all other potential workers. This is in a context that assumes that any worker may undercut the individual, and technology creates a permanent threat to employment security. In practical terms, all labour is disempowered. A weakened institutional position is expressed through 'flexicurity'. Economic policy reduces the role of trade unions, focuses on supply side economics for labour (improving skills and mobility, facilitating matching etc) and places the greater responsibility for systemically constrained outcomes on the individual (you are unproductive, you are insufficiently skilled, mobile, appropriate, valuable, etc.). 
So, from a dominant conceptual point of view policy translates the social human, as a locus of concern that an economy ought to serve, into an economic unit, servile within the needs of a particular kind of economy (though the justification remains that your interests are served by that system). Notably, the claim is that wages are more or less determined by the characteristics of workers in market contexts: what they are prepared to do. This is just or fair and the system will ensure that wages grow fairly, within a just-as-competitive system. This is a central component of a dominant ideational framework, which forms a common sense where markets are the idealised arbiters of all economic activity. This common sense transcends the EU. At its broadest it is built into the dominant neoliberal discourse of globalization (every component must conform to precepts of a particular construct of competition or fall behind).

Of course, globalization as an outcome, is not a cause of anything, it is something to be explained, and this includes the positioning of the very idea of globalization as a necessary reason why states must conform to policy types. What is omitted here is the role of corporations as market actors able to affect what can be done, and the role of the state, and regional and global organizations in creating policy regimes that underpin the scope for activity of different actors, favouring some over others. That is, political power that spreads beyond the polity (as the formal institutions of the state) and which can then facilitate different institutional ways in which wage growth and income growth are reduced over time and more of wealth is captured or concentrated.

There are many further significant aspects to ideational positioning. Most importantly, the centrality of derived demand from labour (the centrality of wages and incomes to growth) is suppressed and the issue of the level of effective demand is neglected. This marginalizes Keynes' central insight regarding the importance of equitable wages and income for the reproduction of a capitalist economy (see Grieve, 2014). Within Keynes' framework institutions are required to ensure limits to inequality. Within the current dominant framework the problem of inequality becomes incoherent. Furthermore, unemployment appears essentially voluntary. There is a 'natural rate'. The possibility of active expansionary fiscal policy and different investment multipliers are marginalized. Socialised investment and orienting and shaping investment for the social good, including along ecological lines where one might emphasise qualitative transformation rather than quantitative destruction becomes conceptually problematic. Fundamental fiscal and investment issues are subsumed and confused, becoming minor temporary or localised singular policy foci rather than system issues. They are translated and limited via the dominant ideational frame, which acts as a kind of obfuscation: that is, selfequilibrating, efficient-as-just, technologically dynamic free markets, imbued with indispensable corporate leadership by pioneering entrepreneurs.

The point to emphasise here is that this common sense is uncommon, but also misleading. It is recognized as unrealistic but is held also as an ideal (a rough 'how things can be and should be'). Its characteristics and timelines vary between states. For example, there are differences between the UK's experience beginning in the late 1970s, and Germany's, whose shift has been more gradual. The Hartz labour market reforms came as late as 2003-2005. However, the common sense has become integral to global, regional and state institutions, expressed in different ways to different degrees, and with different levels of 
resistance and critique (for example through DiEM25). ${ }^{\text {iv }}$ It is the mismatch between this common sense and actually experienced reality, which gives rise to the kinds of grievances expressed through Brexit. This is not simply an issue of left or right politics, though it can carry their traces. Both the Left Exit or Lexit position and the more inchoate combining of migration with moral panic have economic constituents.

The loss of trust expressed by citizens is caused rather than arbitrary (Morgan and Sheehan, 2015a, 2015b). The deep sense that there is one rule for the few and another for the many is created by experience. Intrinsic to this situation is a democratic deficit: where interests that have gradually developed this common sense have captured institutions, including the state. One finds recognizable versions of the common sense within the Washington and postWashington consensus, including the particular policies of the World Bank and IMF, and the coordinating activity of the WTO, as well as the 'Anglo-Saxon' liberal economic model. And one finds it within the Single Market framework of the EU and increasingly within the practices of EU members who are also collectively and individually members and participants in these other institutions. The common sense forms the basis of shared tendencies and these have been variously stated (e.g. Streeck, 2011; 2014).

Hence, being inside or outside of the EU may not in itself be the main issue in terms of Brexit. The nature of globalization is more broadly what is at issue (see Palley and Horn, 2013). It is in many respects a measure of the success of the common sense that critique of globalization and use of terms such as the Washington consensus are loaded, carrying connotations of the political-aspejorative, as though the common sense were simply the technical template of progress, and to question it was to be anti-progress. It is in many ways ironic that the political power that spreads beyond the polity has achieved this, and that to question the rules is somehow against the rules. It remains possible to provide marginal critiques from within the system but it is extremely difficult to get a hearing for critiques of the system (we have Fight Club economics). ${ }^{v}$ Critique becomes a social movement problem typically externalised from policy. This too has become a source of grievance where externalisation has become synonymous with extreme, as though the many were not representative of a significant constituency.

The externalising of fundamental critique needs to be resisted in the name of reasoned argument. It is not anti-progress to question the nature of progress: to ask for whom, on what basis, and with what costs? If one considers the problem of growing inequality over recent decades, Thomas Piketty's work has done much to publicise the increasing concentration of wealth and income among a top 10, 5 and $1 \%$. The very fact that it has become meaningful to empirically differentiate a 1\% (and 5 and 10\%) from the rest indicates that the kinds of grievances expressed in Brexit are not just issues for localised leftbehind minority interests - there is something more systemically pervasive to consider. Moreover, there is more to inequality than simple mechanisms (see Lopez-Bernardo et al 2016; Morgan 2015). Rather there are multiple and developing relations: a complex and varied system of finance, production and trade, a positioning of corporations across many states, and flows of capital and goods. This cannot simply be deemed beneficial by virtue of existence, one must 
also consider its pathologies: financialisation, debt-dependence, exploitation of people and environments, wealth capture as well as wealth creation.

Inequality has manifested to its greatest degree in the USA, but has also occurred within all major economies. The UK has a greater income and wealth differential between the top $10 \%$ and bottom $10 \%$ than the EU average, and this is far higher for the top $1 \%$. One cannot, therefore, attribute the actual level of inequality in the UK to EU membership in some simple way. Inequality varies within the EU, and beyond it. The extent within the UK will owe something to common factors that transcend the EU and then also some combination of factors related to membership (either positive or negative). Voting Leave because of economic grievances arising from inequality, as many apparently did, seems intuitively misconceived. At the same time, being a member of the EU did not prevent inequality and other socio-economic problems that have manifested in Brexit. Though it may be possible to distinguish between what being a member of the EU has been responsible for and what it has not prevented, if one considers the underlying dominant ideational framework then the two start to converge. The real issues are: what are the consequences of the framework and what are the alternatives that might address the grievances otherwise expressed through Brexit?

\section{Be careful what you wish for?}

In the UK, the Leave Campaign theme focused on regaining control. However, this confuses formal separation with autonomy. It is unlikely that the UK will become more independent. It is far more likely that the terms of its dependencies will become more complex. The UK must now decide on its future institutional arrangements. These may range from becoming a member of the European Economic Area (EEA), to pursuing a range of bilateral agreements. There is an immediate problem here since membership of the EEA will likely result in acceptance of free movement preventing effective limits on European migration (a central commitment of Leave). Relatedly, limiting migration from outside of Europe may also be difficult and counterproductive. The UK already has a population that is diverse by ethnicity and country of origin. This legitimately draws in family members. Moreover, the UK has a perpetual need for both specialised high skilled and unskilled labour, and this is situated to an aging demographic and low replacement rate by birth. Various references made by politicians to an Australian style 'points-based' model seems unlikely to be workable in the UK context. Furthermore, one should not neglect that Australia actually has very high levels of immigration. The conflation of economic migration with the issue of asylum in Europe also requires one to remember that Australia's current refugee policy involves offshore isolation and indefinite detention of a kind that contravenes international law and has resulted in widespread vilification.

The main focus of concern stated for the UK's future institutional arrangements is trade relations. Policy discussion is currently about different emphases regarding whom to trade with, rather than more fundamentally, what kind of economy would address the range of problems that gave rise to Brexit. The UK must now negotiate in order to have institutional arrangements in place that can become active no later than two years after Article 50 of the Lisbon 
Treaty is activated (notification of withdrawal). Time is short, resources knowledge and skills to be used in negotiation are limited. This is not a position of power. Moreover, the point of negotiation is not just access to different countries' markets for goods and capital flows, it is relations with corporations as sources of production and finance. The logic of negotiation is not about level playing fields, but rather about competition to attract corporations, whilst articulating the common sense of 'free markets'.

The temptation will be to pursue policies advantageous to rising profit shares: that is, allowing more wealth capture from wealth creation. Typical means to these ends include: lowering corporation tax, providing investment subsidies, emphasising light touch regulation and the flexibility of labour (ability to rapidly hire and fire and suppress wage growth). Various think tanks have already begun to advocate policies along these lines as ways to transform the UK into the 'new Singapore'. They are, however, simultaneously all policy tendencies, which are liable to exacerbate problems such as inequality, whilst transferring greater power to corporations, enabling more capture and reducing accountability. In any case, many modern corporations operate long supply chains with complex production processes in different locales. Being outside of a trading bloc disrupts one's capacity to be part of the chain. This is likely to intensify the need for concessions to attract corporate investment, and also further a temptation to attract reporting of revenues rather than actual economic activity - a tax haven effect. Thereafter, claimed positive consequences of economic policy are articulated through the neoliberal common sense. Innovation, investment, and productivity effects are by definition left as unintended consequences of market interactions: freeing markets leads to entrepreneurial dynamism, and 'better' growth implies marginal productivity gains that are translated into increased real wages. This discourse is familiar: it suggests the solution to current problems is more and intensified versions of the policy justifications that gave rise to the current situation.

Concomitantly, the core concerns of post-Brexit policy in the UK seem likely to be tightly focused on the economy because of the disruption created by Brexit. They are unlikely to be concerned directly with inequality, social mobility, democratic accountability and social cohesion as the problems that helped trigger Brexit. The Referendum, of course, must now mean any ruling party is more aware than ever that these are issues to address. Equally, actually addressing them within dominant ways of thought and policy has become more difficult. If current forecasts of lower economic growth (or recession) prove correct then tax revenues will fall. Based on current dominant common sense for economic policy the result will be further austerity, leading to reductions in welfare spending, and restrictions on state investment, in the context of concerns over budget deficits and long-term net debt. The UK already has recognized problems in terms of its dependency on financial services (perhaps a 'finance curse', Christensen et al, 2016). ${ }^{\mathrm{vi}}$ It also has problems regarding the structure of its economy, translated and restricted by a framework of 'balancing' (Berry and Hay, 2016). Dependency and economic structure problems seem likely to be exacerbated by the need to rely on financial services tax revenue, as well as likely new limits on investment funding, unless the state changes it position on sovereign debt. The UK budget deficit for 2015-16 was $£ 75$ billion and this was higher than forecast, public sector net debt in 2016 stands at $£ 1.6$ trillion or just 
over $83 \%$ of GDP. Missing targets for reductions in deficits, and expectations that deficits will now grow, combined with a continued increase in net debt are all triggers for financial retrenchment within dominant frameworks. This is different than the Treasury merely delaying its commitment to deficit reduction targets (an austerity framework remains ideationally dominant).

Responding to immediate economic dislocations in the absence of a genuinely active fiscal policy will also likely perpetuate the dominance of monetary policy through the role of the Bank of England. Loose monetary policy based on zero-bound interest rates seems likely to continue to constrain the value of savings, and because of the actual technical measures used, the current value of all pensions schemes. Pension scheme liabilities create problems for corporations in terms of funding requirements. This provides further motivations to shed pension liabilities (reducing pension benefits). In the meantime investment is often delayed - so this is one more factor in a situation of uncertainty liable to reduce business investment, despite historic low interest rates. Lower interest rates also affect long-term annuity rates via the discounting calculations applied to bond valuations. The retired, the just-about to retire and those most dependent on the state are set, therefore, to be most adversely affected by the aftermath of Brexit in the UK (and these were all groups who actually tended to vote Leave).

In the end, Brexit is a regional and global issue not just a UK issue. Problems for the UK are also problems for partners and those positioned as competitors. Interactions between separated entities, rather than within integrated ones, create additional grounds for complexity, breakpoints, confusion, distortion and subversion. Brexit may well create problems for current initiatives for collective progress, limited though many of them so far have been. It inserts a new complication into the Trans-Atlantic Trade and Investment Partnership (TTIP) creating a potential distraction from the core problem of corporate accountability. vii It creates further complications for collective solutions to tax avoidance, such as unitary taxation (see Morgan, 2016b). It introduces additional problems into the development and monitoring of mechanisms within the new Paris COP 21 climate change agreement (see Morgan, 2016a; Spash, 2016).viii It may even have knock-on effects in terms of financial stability that exacerbate current problems for the Eurozone. ${ }^{\text {ix }}$ This may call forth more of the same policies that have socialised costs and created extreme distributional harms in some countries (for background, see Patomäki, 2013; Stockhammer, 2016). Both Deutsche Bank and Unicredit are deeply embedded in a set of currently vulnerable relations. Brexit may then signal a lurch in neoliberalism, a further evolution and perhaps its death throes (rather than merely a 'failing forwards').

\section{Conclusion}

At the moment, nothing is certain. Often, talk of crises comes to nothing and in retrospect problems can lose the sense of significance that immediacy gave them. Yet, there is a further danger here. It does not require worse cases to manifest for opportunities for something better to have been lost. We should not need Brexit to be disastrous to realise it signals something important. Systems are fragile and they are fragile because they are constituted through people, but this 
fragility is also a strength because it is the potential for transformative change. One might perhaps argue that the current situation is one of increasing alienation and this alienation is a measure of the fragility of the contemporary world. The term, of course, is deeply unfashionable, but it is worth considering what Marx actually meant (see Wood, 1984). For Marx, alienation expressed itself as a deep sense of inauthenticity, a lack of self-worth or existential meaninglessness, where the actual potentials of the human were somehow being harmed by the system we live in (even as the scope of those potentials was broadening through material progress based on that system). There is something ultimately Aristotelian about this: a recognition that there is a person who can both suffer and flourish. Brexit seems to want to answer this question of suffering and flourishing in partial ways without ever having explicitly asked it. ${ }^{\mathrm{x}}$

\section{References}

Berry, C. and Hay, C. (2016). The Great British Rebalancing Act: The construction and implementation of a economic imperative for exceptional times. British Journal of Politics and International Relations. 18(1), 3-25.

Brenner, N., Peck, J. and Theodore, N. (2010). After Neoliberalization? Globalizations 7(3), 327-345.

Christensen, J. Shaxson, N. and Wigan, D. (2016). The finance curse: Britain and the world economy. British Journal of Politics and International Relations, $18(1), 255-269$.

Duroy, Q. (2014) Neoliberal Europe: Enabling Ethno-Cultural Neutrality or Fuelling Neo-Nationalist Sentiment? Journal of Economic Issues 48(2), 469-476.

Grieve, R. (2014). Right Back Where We Started From: From the Classics to Keynes, and Back Again. Real World Economics Review 68, 41-61.

Lawson, T. (2015) Essays on the Nature and State of Modern Economics. London: Routledge

Longo M, and Murray, P. ( 2011). No ode to joy? Reflections on the European Union's legitimacy. International Politics 48(6): 667-690

Lopez-Bernardo, J. Lopez-Martinez, F. and Stockhammer, E. (2016). A PostKeynesian Response to Piketty's 'Fundamental Contradiction of Capitalism. Review of Political Economy, 28(2), 190-204,

Morgan, J. (2016a). Paris COP 21: Power that speaks the truth? Globalizations, 13(6), forthcoming.

Morgan, J. (2016b). Corporation tax as a problem of MNC organizational circuits: The case for unitary taxation. British Journal of Politics and International Relations, 18(2), 463-481.

Morgan, J. (2015). Piketty's calibration economics: Inequality and the dissolution of solutions? Globalizations, 12(5), 803-823.

Morgan, J. and Sheehan, B. (2015a). Has reform of global finance been misconceived? Policy documents, and the Volcker Rule Globalizations 12 (5), 695-709.

Morgan, J. and Sheehan, B. (2015b). The Concept of Trust and the Political Economy of John Maynard Keynes, illustrated using central bank Forward Guidance and the democratic dilemma in Europe. Review of Social Economy, 73(1), 113-137. 
Ostry, J. Prakash, L. and Furceri, D. (2016). Neoliberalism oversold? Finance \& Development 53(2), 38-41.

Palley, T. and Horn, G. editors (2013). Restoring Shared Prosperity: A Policy Agenda from Leading Keynesian Economists. Creative Space Independent Publishing Platform

Patomäki, H. (2013). The Great Eurozone Disaster: From Crisis to Global New Deal. London: Zed Books.

Peck, J. (2013). Explaining (with) neoliberalism. Territory, Politics, Governance 1(2): 132-157.

Sloam, J. (2016). Diversity and voice: The political participation of young people in the European Union. British Journal of Politics and International Relations 18(3), 521-537

Spash, C. (2016). This changes nothing: The Paris agreement to ignore reality. Globalizations, 13(6), forthcoming.

Stockhammer, E. (2016). Neoliberal growth models, monetary union and the Euro crisis. A post-Keynesian perspective. New Political Economy, 21(4), 365-379

Streeck, W. (2011). The crisis of democratic capitalism. New Left Review, 71, 529.

Streeck, W. (2014). How will capitalism end? New Left Review, 87, 35-64.

Wood, A. (1984). Karl Marx. London, Routledge, Kegan Paul

Wrenn, M. (2014). Unveiling and Deconstructing the Enabling Myths of Neoliberalism Through Immanent Critique. Journal of Economic Issues 48(2), 477-484.

\footnotetext{
i Thanks to Steve Fleetwood and Tony Lawson for comments.

ii There has in the UK, for example, been a breakdown of the social contract between capital and labour, but also a breakdown of intergenerational solidarity. If one looks through recent data and reports from the Institute for Fiscal Studies or the Rowntree Foundation then various trends emerge. The UK economy has increased in size by $50 \%$ since 1995 yet the real income of the average 40 year old (allowing for inflation and housing costs) is approximately what it was in 1995. At the same time actual household debt levels are about twice what they were in 1995. Those below 40 are now increasingly renters $(80 \%$ of those 25 or younger rent or live with their parents), they lack access to final salary pension schemes (there were 5 million private sector scheme members in 1995 and less than 500,000 in 2014), they now carry tuition fee debt, are less likely to be a member of a union, and those unions are weaker than at any time in the last 100 years in terms of the legal scope for action.

iii This is not to suggest the whole is simply reproducing itself without any prospect of fundamental change or transformation.

iv The Democracy in Europe Movement whose initial prime movers include Saskia Sassen, Yanis Varoufakis, Noam Chomsky, Susan George and Tony Negri https://diem25.org

${ }^{v}$ A good example of limited acknowledgements of problems from within the common sense is Ostry et al (2016) published in an IMF journal.

vi Christensen et al (2016, pp. 4-5) argue that advanced economies can suffer a finance curse that is analogous to the recognized resource curse that afflicts some developing economies: cumulative over dependence on a single economic sector has adverse effects on the overall structure and subsequent evolution of a political economy. The UK has the third largest financial sector in the world and is the largest of these by proportion of the economy. It is a centre of financialisation; capital inflows to the financial sector maintain high exchange rates which reduce the capacity of other sectors such as manufacturing to expand via exports (encouraging an import dependency within globalization); finance attracts a disproportionate number of skilled workers who might otherwise contribute to other sectors; the state becomes dependent on tax revenues from the sector (despite tax avoidance) and lobby groups for finance pursue political
} 
capture that cumulatively shapes and distorts policy, encouraging the dislocation of representative democracy from the broader citizenship; the net effect is also to contribute to asset bubbles, periodic financial crises through pro ('light') finance regulation, the socialisation of costs, and a loss of trust in the political system.

vii TTIP is not about reducing real trade barriers between states, since there are few between EU members and the USA, it is mainly about protections of corporate privilege in the name of free trade: strengthening and extending copyright and patents and the creation of extra-judicial mechanisms (Investor-State Dispute Settlements or ISDS) to settle disputes between corporations and states in ways that reduce the capacity of states to intervene in corporate activity in their own jurisdiction since this becomes a barrier to trade. TTIP creates a space for corporations to avoid democratic accountability and augments their power to increase profitability (lobbying has been led by telecoms, finance, pharmaceuticals and the large software firms). Notably TTIP provides a mechanism through which corporations can resist emissions reduction regulation, since interventions can be categorised as trade barriers.

viii The new Conservative government under Theresa May immediately scrapped the Department of Energy and Climate Change and created a Business Energy and Industrial Strategy Department. DECC had three main foci: cheap and secure energy for consumers and businesses, supporting economic growth and reducing carbon emissions. The three are in tension. The new department signals a further transition (already begun under the previous regime) away from prioritising carbon emissions reduction (via the Climate Change Act 2008). Achievement is left to market and technology changes over time.

ixThis has various channels. For example, Brexit will likely cause at least short-term reductions in trading activity in the EU. This in turn may place greater pressure on firms and thus on the banks carrying their debts. Also, some banks continue to carry large volumes of non-performing loan 'assets' and are recycling debt for 'zombie' firms in order not to manifest losses on their accounts (though this varies by country). Fear effects related to anything that might upset this vulnerable position create grounds for collapses in equity as well as withdrawal of corporate deposits. This creates bank funding problems (in REPO markets, etc). Low interest rates also narrow the transformation range for banks, reducing margins/returns on current lending. The overall damage to capitalisation and Tier 1 capital is potentially progressive but also subject to sudden triggers (such as failing a stress test). It creates calls on the state for recapitalisation and socialisation of losses (However, there are new rules for bank equity and bailouts/ins which create new compliance problems with unintended consequences). Italy is a prime candidate for financial crisis, based on these channels. According to the IMF, approximately $18 \%$ of debt at Italian banks is suspect ( $€ 360$ billion).

x Strictly speaking since Brexit involved many differently positioned reasons and arguments then any adequate use of the term alienation must also address the issue of the different degrees of awareness of fundamental issues these positions might involve. For example, the Left Exit or Lexit movement was quite different than the UKIP or Leave inspired positions. Both articulated issues of sovereignty and democratic accountability but involve quite different concepts of what democracy is as an actual form and how it relates to an economy. The Lexit position grew from the 1970s socialist opposition to the then EEC and so might be self-consciously anti-alienation. 